\title{
WPROWADZENIE DO PROBLEMATYKI OPODATKOWANIA „KONTROLOWANYCH SPÓŁEK ZAGRANICZNYCH"*
}

\author{
Do podatków nie wystarczy umyst matematyka; \\ Tutaj potrzebny jest filozof... \\ Albert Einstein
}

\begin{abstract}
WSTĘP
Procesy integracyjne we współczesnej gospodarce można rozpatrywać między innymi przez pryzmat ich oddziaływania na systemy podatkowe poszczególnych państw. Integracja gospodarcza charakteryzuje się bowiem stopniowym zacieraniem się barier ekonomicznych między państwami na całym świecie, co pociąga za sobą również możliwości związane $z$ wykorzystywaniem obcych jurysdykcji podatkowych w celu unikania opodatkowania ${ }^{1}$. Efekt stymulujący unikanie opo-

* Niniejsze opracowanie jest zarazem ogólnym zarysem problematyki rozprawy doktorskiej autora zatytułowanej: Model opodatkowania „kontrolowanych spółek zagranicznych”. Rozprawa doktorska jest pisana w Katedrze Prawa Finansów Publicznych Wydziału Prawa i Administracji Uniwersytetu Mikołaja Kopernika w Toruniu pod naukowym nadzorem prof. dr. hab. Bogumiła Brzezińskiego.

1 W nauce i praktyce prawa podatkowego utrwaliła się koncepcja, zgodnie z którą należy oddzielić pojęcie unikania opodatkowania od pojęcia uchylania się od opodatkowania. To drugie jest bowiem zawsze działaniem sprzecznym z prawem, z którym wiąże się odpowiedzialność karna. Prowadzi ono najczęściej do całkowitej eliminacji ciężarów podatkowych, na przykład przez zatajenie źródeł przychodów czy fałszowanie dokumentów niezbędnych do obliczenia wysokości podatku. Natomiast unikanie opodatkowania jest wyborem takiej formy oraz struktury planowanej transakcji w ramach i granicach obowiązującego prawa podatkowego, w rezultacie której redukowane zostaje obciążenie podatkowe. Ze względu na to, że na odmienne transakcje finansowe oraz konstrukcje prawne nałożone są obciążenia podatkowe różnej wysokości, to wybór tych najkorzystniejszych dla podatnika nie może stanowić naruszenia prawa. Zob. J. E. Stiglitz, The General Theory of Tax Avoidance, „Natonial Tax Journal” 2001, vol. XXXVII, s. 325; L. Templemann, Tackling Tax Avoid-
\end{abstract}


datkowania przypisać można także globalizacji, de facto wpływającej również na procesy integracji w gospodarce. Globalizacja przejawia się w szczególności przez zanikanie barier ekonomicznych, prawnych, politycznych, społecznych, a nawet psychologicznych, które mogłyby ograniczyć swobodny przepływ kapitału lub wpływać na jego lokalizację 2 . Prima facie czynniki integracji gospodarki kreują jej otwartość, co daje potencjalnym inwestorom swobodę w wyborze miejsca lokalizacji swoich interesów. Tym samym globalizacja oraz procesy integracji gospodarki tworzą idealne środowisko gospodarcze do egzystencji i rozwoju zjawiska unikania opodatkowania na poziomie międzynarodowym (international tax avoidance) $)^{3}$.

Jednym $\mathrm{z}$ mechanizmów unikania opodatkowania na poziomie międzynarodowym jest zakładanie spółek w preferencyjnych jurysdykcjach podatkowych. Mechanizm ten realizuje się poprzez transfer dochodów z państwa rezydencji podatkowej udziałowców do kontrolowanych przez nich spółek, które zostały utworzone w państwie o niskim opodatkowaniu dochodów osób prawnych. Wskutek transferu dochodu z państwa rezydencji podatkowej udziałowców do kontrolowanych spółek zagranicznych (dalej: KSZ) założonych w preferencyjnych jurysdykcjach podatkowych dochód ten będzie podlegał opodatkowaniu wyłącznie w państwie siedziby KSZ. W konsekwencji nie zostanie nigdy opodatkowany lub opodatkowanie będzie minimalne. Ewentualne opodatkowanie w państwie rezydencji udziałowców KSZ nastąpi jedynie w przypadku transferu dochodu od KSZ do jej udziałowców w postaci dywidendy. Jednak i w tym przypadku wystąpi korzyść ekonomiczna dla udziałowców w postaci odroczenia terminu zapłaty podatku do momentu transferu dochodów z KSZ. Reasumując, zjawisko to prowadzi do erozji wpływów podatkowych w państwie rezydencji podatkowej udziałowców poprzez transfer dochodu do preferencyjnych jurysdykcji podatkowych. W konsekwencji niektóre państwa wprowadziły szczególne środki prawne mające na celu ograniczenie występowania tego niekorzystnego z punktu widzenia interesów Skarbu Państwa zjawiska ${ }^{4}$. Środki prawne realizujące to za-

ance, [w:] A. Shipwright (ed.), Tax Avoidance and the Law. Sham, Fraud or Mitigation, Key Haven Publications PLC, Oxford 1997, s. 1; w polskiej literaturze zob. m.in. B. Brzeziński, Wstęp do nauki prawa podatkowego, wyd. TNOiK, Torun 2003, s. 87-91.

2 D. M. Kalir, Taking Globalization Seriously: Towards General Jurisprudence, „Columbia Journal of Transnational Law” 2001, no. 39, s. 792-793.

3 S. Kapoor, Commentary on New Code Expected in 2008. Anti-Avoidance and Tax in Small Huge World, „International Transfer Pricing Journal” 2008, no. 1/2, s. 56.

47 państw wprowadziło UKSZ w latach 1962-1990: Stany Zjednoczone w 1962 r., Niemcy (RFN) w 1972 r., Kanada w 1976 r., Japonia w 1978 r., Francja w 1980 r., Wielka Brytania w 1980 r., Nowa Zelandia w 1988 r. Kolejnych 14 państw wprowadziło te przepisy w latach 1990-2000: Australia w 1990 r., Szwecja w 1990 r., Norwegia w 1992 r., Finlandia w 1994 r., Hiszpania w 1994 r., Dania w 1995 r., Portugalia w 1995 r., Korea Południowa w 1996 r., Meksyk w 1997 r., Węgry w 1997 r., RPA w 1997 r., Argentyna w 1999 r. i Wenezuela w 1999 r. Natomiast po 2000 r. UKSZ 
danie nazywane są ustawodawstwem dotyczącym kontrolowanych spółek zagranicznych (dalej: UKSZ)

Celem artykułu jest zapoznanie czytelnika z problematyką unikania opodatkowania na poziomie międzynarodowym z wykorzystaniem KSZ oraz sposobami przeciwdziałania temu zjawisku. W szczególności artykuł przedstawia istotę oraz przesłanki zastosowania UKSZ - przepisów skierowanych przeciwko unikaniu opodatkowania przez wykorzystanie KSZ. W związku z tym, że tego typu przepisy nie występują i nigdy nie występowały w polskim systemie prawa podatkowego, ich charakterystyka została dokonana w oparciu o komparatystyczną analizę ustawodawstwa, orzecznictwa oraz poglądów przedstawicieli doktryny prawa podatkowego państw, w których UKSZ zostały wprowadzone do ustawodawstwa oraz nadal obowiązują.

\section{GRANICE JURYSDYKCJI PODATKOWEJ}

We współczesnej nauce prawa podatkowego wskazuje się, że możność sprawowania jurysdykcji podatkowej jest fundamentalnym elementem suwerenności państwa ${ }^{6}$. Pozwala to poszczególnym państwom na kształtowanie systemów podatkowych w autonomiczny sposób ${ }^{7}$. Przy czym granice jurysdykcji podatkowej, pomimo jej terytorialnego charakteru, nie pokrywają się całkowicie z granicami terytorium państwa. Wynika to z tego, że normy prawne międzynarodowego prawa publicznego nie zawierają zakazu rozciągania władztwa podatkowego państwa poza jego granicami ${ }^{8}$. W konsekwencji jurysdykcja podatkowa państwa może rozciągnąć się poza jego granice, o ile istnieje odpowiedni łącznik podat-

wprowadziły 4 państwa: Estonia w 2000 r.; Włochy w 2000 r., Izrael w 2000 r. i Litwa w 2002 r. Zob. D. Sandler, Controlled Foreign Corporation Rules and Developing Economies. Prezentacja dotycząca przepisów o kontrolowanych spółkach zagranicznych, http://www.fitindia.org/downloads/ Daniel\%20Sandler_2004.pdf (data dostępu: 31.10.2011).

5 Jest to dosłowne tłumaczenie $\mathrm{z}$ języka angielskiego terminu Controlled Foreign Companies Legislation, określanego skrótowo CFC-legislation lub CFC rules. Skrót CFC jest od wielu lat stosowany w nauce i praktyce międzynarodowego i europejskiego prawa podatkowego dla określenia przepisów przeciwdziałających unikaniu opodatkowania poprzez zakładanie spółek w państwach o preferencyjnych systemach podatkowych.

6 A. Biegalski, Jurysdykcja podatkowa, [w:] B. Brzeziński (red.), Prawo podatkowe. Teoria. Instytucje. Funkcjonowanie, TNOiK 2009, s. 124.

7 J. Białocerkiewicz, Status prawny cudzoziemca w świetle standardów międzynarodowych, Torun 1999, s. 337; A. Biegalski, Pojęcie i zakres jurysdykcji podatkowej państwa, „Kwartalnik Prawa Podatkowego" 1999, nr 1, s. 89; J. Martha, The Jurisdiction to Tax in International Law. Theory and Practice of Legislative Fiscal jurisdiction, Denver-Boston 1989, s. 13.

K. Vogel, Klaus Vogel on Double Taxation Conventions. A Commentary to the OECD-UN-and US Model Convention for the Avoidance of Double Taxation on Income and Capital, Haga-London-Boston 1997, s. 11; A. Biegalski, Jurysdykcja podatkowa..., s. 125. Por. wyrok Stałego Trybunału 
kowy rozumiany jako podmiotowa lub przedmiotowa przesłanka będąca częścią podatkowoprawnego stanu faktycznego. Innymi słowy, łączniki podatkowe można zdefiniować jako wyraz racjonalnej i akceptowalnej przez inne państwa więzi, występującej między podmiotem i przedmiotem opodatkowania a terytorium państwa nakładającego podatek ${ }^{9}$.

W ogólności można stwierdzić, że łączniki podatkowe dzielą się na podmiotowe i przedmiotowe.

Łączniki podmiotowe zwane są także łącznikami rezydencji i odnoszą się do cech statusu podatnika powstałych w określonym państwie. W odniesieniu do osób fizycznych łącznikiem podatkowym jest najczęściej miejsce zamieszkania, natomiast w przypadku osób prawnych siedziba lub miejsce zarządu ${ }^{10}$.

Z kolei łączniki przedmiotowe odnoszą się do lokalizacji źródła przychodu, miejsca położenia rzeczy lub wykonywania praw. W tym miejscu wskazać należy, że łączniki podmiotowe, co do zasady, związane są nieograniczoną odpowiedzialnością podatkową, natomiast łączniki przedmiotowe $\mathrm{z}$ ograniczoną odpowiedzialnością podatkową. Zgodnie z zasadą nieograniczonej odpowiedzialności podatkowej osoby fizyczne i prawne będące rezydentami podatkowymi danego państwa podlegają obowiązkowi podatkowemu w tym państwie od całości swoich dochodów bez względu na miejsce ich uzyskania ${ }^{11}$. Natomiast ograniczona odpowiedzialność podatkowa zakłada, że opodatkowaniu w danym państwie podlegają tylko te dochody podatnika, które osiągnął na terytorium tego państwa.

Sprawiedliwości Międzynarodowej w sprawie Affaire du Lotus, 7 sèptembre 1927 (France c. Turquie), Recueil des Arre',ts, Sèrie A, No 10, Leyde 1927.

9 A. Biegalski, Jurysdykcja podatkowa..., s. 129.

$10 \mathrm{Za}$ osobę mającą miejsce zamieszkania na terytorium Rzeczypospolitej Polskiej uważa się osobę fizyczną, która (i) posiada na terytorium Rzeczypospolitej Polskiej centrum interesów osobistych lub gospodarczych (ośrodek interesów życiowych) lub (ii) przebywa na terytorium Rzeczypospolitej Polskiej dłużej niż 183 dni w roku podatkowym. Zob. art. 3 Ustawy o podatku dochodowym od osób fizycznych z 26 lipca 1991 r., Dz. U. nr 80, poz. 360, ze zm. Por. art. 3 Ustawy o podatku dochodowym od osób prawnych z 15 lutego 1992 r., Dz. U. nr 21, poz. 86, ze zm. W poszczególnych umowach o unikaniu podwójnego opodatkowania istnieją tzw. kryteria preferencji, które pozwalają rozstrzygnąc zakres jurysdykcji podatkowej, w przypadku braku rozstrzygnięcia w oparciu o łączniki podatkowe. Najważniejszym kryterium preferencji w tym zakresie jest kryterium miejsca sprawowania faktycznego (efektywnego) zarządu rozumianego jako miejsce spotkań i podejmowania kluczowych dla spółki decyzji przez członków jej zarządu. Zob. Point 21of the Commentary on the provisions of the Article 4 of the Model Tax Convention On Income And On Capital. Condensed Version 22 July 2010. OECD - Organization for Economic Co-operation and Development.

11 W literaturze anglojęzycznej tę zasadę nazywa się unlimited tax liability lub worldwide tax income. Zob. K. Vogel, Taxation of Foreign Income - Principles and Practice, BIFD 1985, s. 4 i n. Przykładem państwa, który nie stosuje zasady nieograniczonego obowiązku podatkowego w odniesieniu do opodatkowania osób prawnych jest Francja. Państwo to stosuje we wskazanym zakresie zasadę terytorialności, zgodnie z którą francuskie osoby prawne płacą podatki jedynie od dochodów uzyskanych na terytorium tego państwa. Zob. artykuł 209 I Francuskiego Kodeksu Podatkowego (Code Général des Impôt, Version consolidée au 1 septembre 2011). 
Zatem, jeżeli osoba fizyczna lub osoba prawna jest udziałowcem zagranicznej spółki posiadającej osobowość prawną, wtedy dochody tej spółki nie podlegają opodatkowaniu w państwie rezydencji jej udziałowców. Spółka posiadająca osobowość prawną jest bowiem odrębnym od jej udziałowców podatnikiem i jako nierezydent podatkowy jej dochody podlegają opodatkowaniu w innym państwie wyłącznie, gdy są uzyskiwane na jego terytorium ${ }^{12}$. W szczególności dochody zagranicznej spółki mogą być opodatkowane w państwie innym niż państwo jej rezydencji, jeżeli osiąa ona dochód w tym państwie za pośrednictwem zakładu w rozumieniu art. 5 Modelu Konwencji w Sprawie Podatków od dochodu i Majątku opracowanego przez Komitet do spraw Podatkowych Organizacji Współpracy Gospodarczej i Rozwoju (dalej: MK OECD) ${ }^{13}$. W konsekwencji udziałowcy zagranicznej spółki nie podlegają obowiązkowi podatkowemu z tytułu dochodów, które ona uzyskuje, ale mają obowiązek zapłacenia podatku od dywidend, należności licencyjnych oraz odsetek wypłacanych do nich przez tę spółkę. Nie są to jednak dochody spółki zagranicznej opodatkowane w państwie rezydencji podatkowej jej udziałowców, lecz bierne dochody udziałowców spółki zagranicznej. Zatem, jak zostało to wcześniej wskazane, udziałowcy mogą odroczyć moment zapłaty podatku w państwie ich rezydencji podatkowej poprzez założenie spółki zagranicznej w państwie, w którym dochody osób prawnych nie podlegają opodatkowaniu lub opodatkowanie to kształtuje się na bardzo niskim poziomie. Jeżeli nie dojdzie do dystrybucji dochodów od spółki zagranicznej do jej udziałowców, wtedy udziałowcy zredukują ciężar podatkowy w państwie ich rezydencji do minimum.

\section{ISTOTA UKSZ}

Geneza UKSZ sięga lat 30. XX wieku, kiedy to Kongres Stanów Zjednoczonych w 1934 roku wprowadził przepisy skierowane przeciwko unikaniu opodatkowania przez osoby fizyczne poprzez zakładanie spółek będących od nich odrębnymi podatnikami ${ }^{14}$. Przyczyną wprowadzenia tych przepisów było dużo wyższe opodatkowanie dochodów osób fizycznych w porównaniu z opodatkowaniem osób

12 Zob. art. 30 Ustawy z 23 kwietnia 1964 r. - Kodeks cywilny, Dz.U. nr 16, poz. 93 ze zm. w zw. z art. 12 Ustawy z dnia 15 września 2000 r. - Kodeks spółek handlowych, Dz.U.00.94.1037 ze zm. oraz art. 1 ust. 1 Ustawy z 15 lutego 1992 r. o podatku dochodowym od osób prawnych.

13 W rozumieniu ostatniej wersji MK OECD z 2010 r. określenie „Zakład” oznacza stałą placówkę, przez którą całkowicie lub częściowo prowadzona jest działalność gospodarcza przedsiębiorstwa.

14 Revenue Act of 1934, ch. 277, § 351, 48 Stat. 751, a następnie Internal Revenue Code of 1954, §§ 541-47. 
prawnych ${ }^{15}$. Przepisy te nazywały się incorporated pocketbocks i pozwalały na nałożenie dodatkowego podatku wyrównawczego od dochodu spółek holdingowych, jeżeli minimum $80 \%$ tego dochodu obejmowało zyski z dywidend, odsetek, należności licencyjnych, wynajmu lub sprzedaży udziałów (dochody bierne) ${ }^{16}$.

Przepisy UKSZ w ich obecnym rozumieniu po raz pierwszy wprowadzone zostały do systemu prawa podatkowego w Stanach Zjednoczonych w 1962 roku jako „Subpart F” United States Internal Revenue Code (Amerykański Kodeks Podatkowy $)^{17}$. Amerykańskie UKSZ służyło w sposób bezpośredni lub pośredni jako wzorzec do wprowadzenia tego typu przepisów w niektórych państwach ${ }^{18}$.

W poszczególnych państwach treść UKSZ kształtuje się odmiennie, jednak ich wpólnym celem jest zapobieżenie erozji podstawy opodatkowania w państwie rezydencji udziałowców kontrolowanych spółek zagranicznych poprzez transfer dochodu do państw o preferencyjnych systemach podatkowych, w których mają siedzibę te spółki (odroczenie lub brak opodatkowania tego dochodu) ${ }^{19}$. Inne $\mathrm{z}$ wymienianych $\mathrm{w}$ literaturze celów UKSZ to między innymi zapewnienie neutralności eksportu kapitału, równości opodatkowania czy też skuteczności kontroli podatkowej ${ }^{20}$.

Z dużą dozą ogólności można stwierdzić, że stosowanie UKSZ pozwala na opodatkowanie dochodu uzyskanego przez spółkę zagraniczną w państwie siedziby/miejsca zarządu lub miejsca zamieszkania jej wspólnika/wspólników

15 Dla przykładu stawka podatkowa od 1913 r. w podatku dochodowym od osób fizycznych wynosiła 6\%, natomiast w przypadku osób prawnych 1\%, Revenue Act of 1913, ch. 16, §§ IIA, IIG (a), 3 Stat. 166. Z kolei od 1934 r. stawki te wynosiły odpowiednio w przypadku osób fizycznych 59\%, a w przypadku osób prawnych 13,75\%, Revenue Act of 1934, ch. 277, §§ 12 (b), 13 (a).

16 W. D. Popkin, The Taxation of Foreign Incorporated Pocketbooks With Nonresident Alien Sharebolders, „20 Rutgers Law Review” 1965-1966, no. 268, s. 268 i n.

17 Pełna treść „Subpart F” jest dostępna na oficjalnej stronie IRS: http://www.irs.gov/irm/ part4/irm_04-061-007.html\#d0e74.

18 Najbardziej jaskrawym przykładem „kopiowania” amerykańskich UKSZ były działania podjęte przez niemieckiego ustawodawcę, który wprowadził UKSZ w 1972 r. (Hinzurechnungsbesteuerung). Niemieckie UKSZ są niemalże dosłowną kopią amerykańskich przepisów Subpart F. Warto zauważyć, że Niemcy (wówczas Republika Federalna Niemiec) wprowadziły UKSZ jako pierwsze państwo członkowskie Wspólnot Europejskich. Zob. więcej: A. Rust, National Report Germany, [w:] M. Lang, H.-J. Aigner, U. Scheuele, M. Stefaner (ed.), CFC Legislation, Tax Treaty and EC Law, „Eucotax on European Taxation Series, Kluwer Law International” 2004, vol. 8, s. 257 i n. Podobną metodologię podczas wprowadzania UKSZ przyjął ustawodawca francuski i japoński. Tym razem jako wzorzec przyjęto niemieckie UKSZ. Zob. J. B. Arnold, The Taxation of Controlled Foreign Corporations: An International Comparison, Canadian Tax Foundation, Toronto 1986, s. 406 i n.

19 Szczegółową analizę prawnoporównaczą UKSZ można odnaleźć w literaturze anglojęzycznej. Zob. w szczególności: A. J. Brian, J. A. Hugh, Comparative Income Taxation: A Structural Analysis, 2nd edition, The Hague: Kluwer Law International 2004, s. 406-520.

20 G. Maisto, P. Pistone, A European Model for Member States' Legislation on the Taxation of Controlled Foreign Subsidiaries (CFCs) - Part 1, European Taxation, October 2008, s. 505-506. 
(udziałowców). Następuje to poprzez przypisanie dochodu spółki zagranicznej do jej kwalifikowanych udziałowców, którymi mogą być zarówno osoby prawne, jak i osoby fizyczne, a następnie opodatkowanie tego dochodu w państwie rezydencji udziałowców. W celu przypisania dochodu zagranicznej spółki jej udziałowcom stosuje się dwie alternatywne metody wykorzystania UKSZ konstytuujące dwojakiego rodzaju fikcję prawną: (i) pozbawienie zagranicznej spółki przymiotu osobowości prawnej, a więc również odrębnej podmiotowości podatkowoprawnej ( $\mathrm{z}$ ang. disregarded legal entity approach/piercing corporate veil approach), co skutkuje opodatkowaniem jej tak jak zagranicznego zakładu krajowych udziałowców, lub (ii) uznanie, że dochód niewypłacony udziałowcom spółki zagranicznej został im wypłacony (deemed dividend approach).

$\mathrm{Z}$ powyższego wynika, że stosowanie UKSZ de facto wykracza poza opisane wcześniej granice jurysdykcji podatkowej i związanej z nią zasady opodatkowania osób prawnych. Na opodatkowanie dochodu zagranicznej spółki w państwie jej udziałowców nie pozwala bowiem żaden z łączników podatkowych, gdyż: (i) łącznik podmiotowy umożliwia opodatkowanie dochodu wyłącznie w państwie rezydencji podatnika (zagranicznej spółki), natomiast (ii) łącznik przedmiotowy uzależnia możliwość opodatkowania przede wszystkim od miejsca uzyskiwania przychodu przez podatnika. W przypadku stosowania UKSZ następuje opodatkowanie dochodu spółki zagranicznej w państwie rezydencji jej udziałowców, mimo że nie posiada ona rezydencji podatkowej tego państwa oraz nie uzyskuje dochodu na jego terytorium. Należy zauważyć również, że do zapłaty podatku od dochodu spółek zagranicznych są zobligowani ich udziałowcy, choć w rzeczywistości nie uzyskują oni żadnego dochodu. Natomiast, co do zasady, podatek dochodowy jest naliczany od przysporzeń majątkowych otrzymanych lub przynależnych, a zatem takich, które charakteryzują się definitywnym przyrostem majątku podatnika ${ }^{21}$. W konsekwencji obowiązek zapłaty podatku przez udziałowców zagranicznej spółki w odniesieniu do jej dochodu jest sprzeczny z ogólnie przyjętą definicją dochodu podlegającego opodatkowaniu, gdyż mimo braku przyrostu majątku udziałowcy są zobowiązani do zapłaty podatku. W praktyce stosowania UKSZ występują także wątpliwości dotyczące ich zgodności z międzynarodo-

21 Zob. P. Małecki, M. Mazurkiewicz, CIT. Podatki i Rachunkowość. Komentarz do art.12 ustawy o podatku dochodowym od osób prawnych, wyd. 2, LEX 2011, wersja elektroniczna, LEX I. Zob. także wyrok Naczelnego Sądu Administracyjnego w Warszawie z dnia 16 listopada 2006 r., sygn akt II FSK 1375/05, LEX nr 291825: „Cecha należności dotyczy kwot, które są wymagalne w rozumieniu prawa cywilnego, a zatem zasadne jest przyjęcie, iż przychodami [...] stają się kwoty, których podatnik może skutecznie się domagać od swego kontrahenta”. 
wym prawem podatkowym oraz z prawem unijnym, jednak nie zostanie to szerzej opisane, gdyż objętość niniejszego opracowania na to nie pozwala ${ }^{22}$.

\section{PRZESŁANKI ZASTOSOWANIA UKSZ}

W celu zastosowania materialnej normy prawa podatkowego, w tym UKSZ, musi wystąpić podatkowoprawny stan faktyczny zawarty w tej normie ${ }^{23}$. W szerokim znaczeniu podatkowoprawny stan faktyczny obejmuje ogół podmiotowych i przedmiotowych przesłanek, z których zaistnieniem wiąże się powstanie stosunku podatkowoprawnego ${ }^{24}$. W przypadku UKSZ wystąpienie podatkowoprawnego stanu faktycznego umożliwia opodatkowanie dochodu KSZ w państwie rezydencji jej udziałowców. Obowiązek zapłaty tego podatku spoczywa na udziałowcach KSZ w proporcji do posiadanych udziałów. Na przykład, jeżeli poszczególni udziałowcy posiadają po 10\% udziałów w KSZ, zostanie im przypisane 10\% dochodu KSZ, a następnie będą zobowiązani do zapłaty podatku od tego dochodu. Opodatkowanie udziałowców i wszystkie kwestie z tym związane, w szczególności ustalenie podstawy opodatkowania oraz zastosowanie właściwych stawek podatkowych, regulują przepisy krajowe obowiązujące w systemie podatkowym państwa ich rezydencji ${ }^{25}$.

Przesłanki składające się na podatkowoprawny stan faktyczny UKSZ można podzielić na podmiotowe i przedmiotowe. W celu zastosowania UKSZ opisane poniżej przesłanki muszą być spełnione kumulatywnie ${ }^{26}$.

22 Zob. M. Lang, CFC Regulations and Double Taxation Treaties, „Bulletin - Tax Treaty Monitor”, February 2005, s. 51-58; J. Prebble, Controlled Foreign Company Regimes and Double Taxation, „Asia-Pacific Tax Bulletin”, January/February 2006, s. 3-5; M. Lang, CFC Legislation and Community Law, „European Taxation”, September 2002, s. 374-379; P. Eckl, The Tax Regime for Controlled Foreign Corporations, „European Taxation”, January 2003, s. 7; J. Schönfeld, The Cadbury Schweppes Case: Are the Days of the United Kindon's CFC Legislation Numbered? „European Taxation”, October 2004, s. 441-452; H.-J. Aigner, U. Scheuerle, M. Stefaner, General Report, [w:] CFC Legislation, Tax Treaty and EC Law..., s. 41-43; R. Fontana, The Uncertain Future of CFC Regimes in the Member States of the European Union - Part I (s. 259 - 267) E' II (s. 317 - 334), ET, June/July 2006; A. Joseph, Changes to Controlled Foreign Company Rules, „Derivatives \& Financial Instrument” May/June 2008, s. 102.

23 A. Hensel, Steuerrecht, wyd. 3, Berlin 1927, s. 26.

24 I. Korczyński, Podatkowoprawny stan faktyczny, [w:] B. Brzeziński (red.), Prawo podatkowe. Teoria. Instytucje. Funkcjonowanie, TNOiK 2009, s. 31.

25 T. Honjo, Cabiers de droit fiscal international: Limits on the Use of Low-Tax Regimes by Multinational Business: Current Measures and Emerging Trends, vol. LXXXVIb (2001), s. 647.

${ }^{26} \mathrm{~W}$ pewnych przypadkach niespełnienie którejś przesłanki przy jednoczesnym wystąpieniu określonych okoliczności nadal pozwala na zastosowanie UKSZ oraz odwrotnie - wystąpienie wszystkich przesłanek może nie pociągać za sobą zastosowania UKSZ, jeżeli wystąpi któryś z wyjątków od zastosowania UKSZ. 
Do przesłanek podmiotowych należy status podatkowy zagranicznej spółki oraz status podatkowy krajowych udziałowców.

Zagraniczna spółka musi być rezydentem podatkowym innego państwa niż państwo rezydencji podatkowej jej udziałowców oraz być odrębnym od jej udziałowców podatnikiem ${ }^{27}$. W przeciwnym bowiem wypadku (rezydencja w państwie udziałowców lub transparentność podatkowa) zastosowanie UKSZ byłoby bezcelowe ze względu na możliwość opodatkowania spółki zagranicznej w państwie jej udziałowców w oparciu o podmiotowy łącznik podatkowy (zasada nieograniczonego obowiązku podatkowego).

W przypadku udziałowców KSZ występuje reguła „lustrzanego odbicia” w stosunku do statusu podatkowego zagranicznej spółki. Mianowicie udziałowcy KSZ muszą mieć status rezydenta podatkowego, a więc posiadać nieograniczoną odpowiedzialność podatkową ze względu na miejsce zamieszkania (osoby fizyczne) lub siedzibę/miejsce sprawowania zarządu (osoby prawne), państwa innego niż państwo rezydencji zagranicznej spółki.

Z kolei przesłanki przedmiotowe obejmują stopień kontroli zagranicznej spółki przez jej udziałowców, poziom opodatkowania zagranicznej spółki w państwie jej rezydencji oraz rodzaj dochodu podlegającego opodatkowaniu.

Co do zasady, spółka zagraniczna jest uznawana za kontrolowaną, jeżeli krajowy udziałowiec posiada w sposób bezpośredni lub pośredni ponad 50\% jej udziałów (akcji) lub praw głosu na walnym zgromadzeniu wspólników (kontrola de iure $)^{28}$. W takim wypadku występuje domniemanie posiadania przez krajowego udziałowca znaczącego wpływu na podejmowanie kluczowych decyzji dotyczących spółki zagranicznej. W tym miejscu należy wyjaśnić, że 50\% próg kontroli zagranicznej spółki jest spełniony, jeśli udziałowiec posiada wskazaną ilość udziałów lub prawa głosu w zagranicznej spółce w danym roku podatkowym łącznie z podmiotami powiązanymi w rozumieniu właściwych przepisów. W związku z tym, że taka koncepcja kontroli zagranicznej spółki mogłaby prowadzić do opodatkowania udziałowca posiadającego 1\% i mniej udziałów w zagranicznej spółce

27 Zatem dotyczy to wyłącznie spółek zagranicznych posiadających osobowość prawną. O tym, czy dana spółka posiada osobowość prawną, decydują właściwe przepisy krajowe państwa, w którym ta spółka została założona. Zgodnie z prawem podatkowym niektórych państw, spółki osobowe są podatnikami podatku dochodowego, podczas gdy w innych państwach są to podmioty transparentne podatkowo i tylko ich wspólnicy podlegają opodatkowaniu. Zob. więcej: Raport OECD, Stosowanie Modelu Konwencji OECD do spótek osobowych, 1999, punkt 19 i 58; w literaturze: F. Wassermeyer, Die Auslegung von Doppelbesteuerungsabkommen durch den Bundesfinanzhof, 67 Steuer und Wirtschaft, 1990, s. 406.

${ }_{28}$ Niektóre państwa przyjęły także tzw. założycielskie prawo kontroli, zgodnie z którym za kontrolowaną uznaje się także spółkę, w stosunku do której udziałowcy mają określone prawa zarządcze przyznane im w statucie spółki lub innym dokumencie inkorporacyjnym. Dotyczy to np. Wielkiej Brytanii i Stanów Zjednoczonych. Zob. R. Fontana, The Uncertain Future of CFC Regimes in the Member States of the European Union - Part I, „European Taxation”, June 2006, s. 260. 
(jeżeli wspólnie z pozostałymi udziałowcami posiada więcej niż 50\% udziałów), większość państw stosujących UKSZ uzależnia prawo do nałożenia na udziałowców obowiązku zapłaty podatku od posiadania przez każdego z nich z osobna nie mniej niż 10\% udziałów zagranicznej spółki ${ }^{29}$.

Co do przesłanki dotyczącej poziomu opodatkowania zagranicznej spółki, to jest ona zależna od przyjęcia jednej z dwóch koncepcji. Pierwsza przewiduje możliwość zastosowania UKSZ niezależnie od poziomu opodatkowania dochodu KSZ oraz preferencji podatkowych, które im przysługują w państwie ich rezydencji (global/transactional approach). Jednak zgodnie $z$ tą koncepcją UKSZ mają zastosowanie wyłącznie w odniesieniu do biernego dochodu (w szczególności dywidendy, odsetki, należności licencyjne). Natomiast zgodnie z drugą koncepcją, UKSZ są stosowane jedynie w przypadku, gdy poziom opodatkowania dochodu KSZ jest niższy od poziomu opodatkowania spółek w państwie rezydencji jej udziałowców (jurisdictional approach). W tym przypadku państwa stosujące UKSZ ustalają określone progi ułamkowe, w oparciu o które dokonuje się porównania efektywnego poziomu opodatkowania spółek w państwie rezydencji udziałowców z poziomem opodatkowania spółek w państwie rezydencji spółki zagranicznej ${ }^{30}$. W ogólności, na potrzeby stosowania UKSZ podatek zapłacony przez zagraniczną spółkę uznaje się za niższy od podatku, który byłby przez nią zapłacony w państwie rezydencji jej udziałowców, jeżeli w danym roku podatkowym wynosi on mniej niż określony ułamek podatku, który podlegałby zapłacie w odniesieniu do tego samego dochodu w państwie rezydencji jej udziałowców ${ }^{31}$. Obrazuje to następujący przykład: w państwie A (rezydencja udziałowców) podatek dochodowy od osób prawnych wynosi 20\%, natomiast w państwie B (rezydencja zagranicznej spółki) podatek od tego samego dochodu wynosi 5\%. W odniesieniu do obu jurysdykcji nie występują żadne zwolnienia czy też ulgi od tego podatku, zatem wskazane stawki procentowe są efektywnymi stawkami procen-

29 Jest to racjonalne rozwiązanie, zważywszy na to, że udziałowiec posiadający nieznaczną ilość udziałów w zagranicznej spółce po pierwsze nie ma żadnego wpływu na jej zarządzanie/kontrolę, a po drugie praktycznie niemożliwe jest uzyskanie przez niego informacji niezbędnych organom podatkowym do opodatkowania dochodu KSZ „w jego rękach” (np. deklaracje podatkowe zagranicznej spółki, sprawozdania finansowe). Niezależnie od tych argumentów, niektóre państwa nakładają obowiązek zapłaty podatku na udziałowca, który posiada 1\% lub mniej udziałów w zagranicznej spółce, np. Kanada.

30 Efektywny poziom opodatkowania lub efektywna stawka procentowa podatku oznacza stosunek podatku faktycznie zapłaconego do osiągniętego zysku brutto. Zatem bierze się pod uwagę podatek faktycznie zapłacony, a nie podatek podlegający zapłaceniu.

31 Państwa stosujące UKSZ najczęściej przyjmują wskaźniki porównywalności poziomu opodatkowania między państwem rezydencji podatkowych udziałowców a państwem rezydencji podatkowej zagranicznej spółki o wartościach: 3/4, 1/2 lub 1/4. Niemniej jednak niektóre państwa, np. Niemcy, uznają za niższe opodatkowanie na potrzeby stosowania UKSZ każde opodatkowanie faktycznie niższe niż średnie opodatkowanie dochodów spółek obowiązujące w tym państwie (obecnie 25\%). 
towymi podatku. Zgodnie z UKSZ państwa A, niższe opodatkowanie występuje, jeśli podatek zapłacony w danym roku podatkowym przez KSZ wynosi mniej niż $3 / 4$ kwoty podatku, który zostałby zapłacony w państwie A z tytułu dochodu osób prawnych. W związku tym, że podatek, który musi być faktycznie zapłacony w państwie $B$, stanowi mniej niż $3 / 4$ podatku do zapłaty w państwie $A$, przesłanka niższego opodatkowania na potrzeby zastosowania UKSZ w państwie A została spełniona. Warto również zauważyć, że państwa stosujące tę koncepcję UKSZ często sporządzają listy jurysdykcji podatkowych, w stosunku do których UKSZ mają całkowite, ograniczone lub wyłączone zastosowanie. Są to odpowiednio tzw. czarne, szare i białe listy jurysdykcji podatkowych ${ }^{32}$.

Przesłanka dotycząca rodzaju dochodu podlegającego opodatkowaniu jest również uzależniona od przyjętej koncepcji stosowania UKSZ. Pierwsza koncepcja pozwala na zastosowanie UKSZ w odniesieniu do każdego rodzaju dochodu uzyskiwanego przez KSZ (entity approach) ${ }^{33}$. Natomiast druga koncepcja pozwala na opodatkowanie KSZ jedynie w stosunku do dochodów biernych (transactional approach). Prima vista głównym skutkiem zastosowania pierwszej koncepcji jest realizacja zasady neutralności eksportu kapitału ${ }^{34}$. Natomiast druga koncepcja jest zdecydowanie bliższa walce $\mathrm{z}$ unikaniem opodatkowania, jako że unikanie opodatkowania od dochodów biernych jest dużo łatwiejsze do zrealizowania niż w przypadku dochodów o charakterze czynnym (np. dochody produkcyjne), ponieważ dochody bierne podlegają łatwemu transferowi oraz trudniej jest ustalić ich faktycznego odbiorcęe $e^{35}$.

Warto zauważyć, że w praktyce stosowania UKSZ koncepcje dotyczące poziomu opodatkowania oraz rodzaju dochodu podlegającemu opodatkowaniu występują rzadko w „czystych” postaciach i najczęściej stosuje się formy mieszane. W nauce prawa podatkowego można odnaleźć opinię, zgodnie z którą koncepcje te należy uznać raczej za uzupełniające się niż za wykluczające się wzajemnie ${ }^{36}$.

32 Sporządzanie przez państwa będące członkami OECD wspomnianych list jurysdykcji podatkowych wynika z zaleceń OECD dotyczących walki ze szkodliwą konkurencją podatkową. Zob. OECD Report on Harmful Competition - An Emerging Tax Issue, $1998 \mathrm{r}$.

33 Niemniej jednak w tym przypadku najczęściej wyłączony z opodatkowania jest dochód czynny pochodzący z rzeczywistej działalności ekonomicznej.

34 Zasada neutralności eksportu kapitału zakłada, że inwestycje w kraju i za granicą powinny charakteryzować się takim samym obciążeniem podatkowym. Zasadę tę realizuje się poprzez opodatkowanie zagranicznego dochodu w kraju w sposób niwelujący korzyść podatkową uzyskaną za granicą (opodatkowanie niższe od krajowego). Zob. S. Kuros, Niektóre aspekty opodatkowania inwestycji bezpośrednich w świetle polsko-niemieckiej umowy o unikaniu podwójnego opodatkowania, „Monitor Podatkowy” 2000, nr 5, wersja elektroniczna: http://www.monitorpodatkowy.pl/index. php?mod=m_artykuly\&cid $=35 \&$ \&id $=215$.

35 J. Prebble, op. cit., s. 3.

36 Zob. R. Fontana, op. cit., s. 261. 
Państwa stosujące UKSZ przewidują wyjątki od zastosowania UKSZ, pomimo kumulatywnego spełnienia powyższych przesłanek. Do najczęstszych wyjątków w tym zakresie należą: (1) wyjątek dystrybucyjny - transfer znacznej ilości dochodów z KSZ do jej udziałowców w danym roku podatkowym, (2) wyjątek dochodu czynnego - dochód KSZ jest w głównej mierze dochodem o charakterze czynnym, pochodzącym z rzeczywistej działalności gospodarczej, (3) wyjątek notowania na giełdzie - KSZ jest spółką publiczną, (4) wyjątek motywacyjny podatnik wykaże, że głównym motywem posiadania udziałów w KSZ lub jej założenie nie jest spowodowane wyłącznie chęcią uzyskania korzyści podatkowych oraz (5) wyjątek de minimis - dochód podlegający opodatkowaniu przy zastosowaniu UKSZ jest nieznaczny.

Poszczególne wyjątki kształtują się odmiennie najczęściej w zależności od tego, czy między państwem rezydencji udziałowców a państwem rezydencji KSZ jest zawarta umowa o unikaniu podwójnego opodatkowania, a także od tego, czy te państwa są członkami Unii Europejskiej/Europejskiego Obszaru Gospodarczego, lub od tego, czy państwo rezydencji podatkowej KSZ uznawane jest za raj podatkowy ${ }^{37}$.

\section{ZAKOŃCZENIE}

Wstępna analiza UKSZ pozwala skonstatować, że stosowanie tych przepisów może prowadzić do zmniejszenia się ilości zagranicznych inwestycji realizowanych przez krajowych przedsiębiorców, a w konsekwencji do utrudnień w rozwoju gospodarczym oraz rynku wewnętrznego. Jest to związane przede wszystkim z obowiązkiem dokumentacji relacji zachodzących między krajowymi udziałowcami i kontrolowanymi spółkami zagranicznymi. W szczególności dotyczy to wskazania wysokości dochodu wytworzonego przez KSZ oraz ekonomicznego uzasadnienia jej działalności. W konsekwencji stosowanie UKSZ może prowadzić do wzrostu sporów między podatnikami a organami podatkowymi w odniesieniu do wskazania podstawy opodatkowania podatkiem dochodowym krajowych udziałowców kontrolowanych spółek zagranicznych.

Z drugiej strony, brak UKSZ prowadzi do erozji wpływów podatkowych w państwach rezydencji udziałowców KSZ, wzrostu szkodliwej konkurencji po-

37 Od 2 listopada 2011 r. już tylko dwie jurysdykcje podatkowe - Nauru i Niue - pozostały sklasyfikowane przez OECD jako raje podatkowe (tax havens), gdyż OECD za główne kryterium tej klasyfikacji uznaje brak współpracy z tą organizacją w dziedzinie transparentności i wymiany informacji podatkowych. Zob. OECD Progress Report on the Jurisdictions Surveyed by the OECD Global Forum in Implementing the Internationally Agreed Tax Standard, http://www.oecd.org/dataoecd/50/0/43606256.pdf. 
datkowej oraz jest przyczyną nierówności opodatkowania. $Z$ powyższego wynika, że UKSZ są trudne do implementowania, co oczywiście nie oznacza, że ich wprowadzenie do krajowego systemu podatkowego jest niemożliwe lub niepotrzebne. Wprost przeciwnie, można postawić tezę, że UKSZ powinny zostać wprowadzone do ustaw o podatkach dochodowych w państwach rozwiniętych i rozwijających się, w których opodatkowanie dochodów spółek kształtuje się na wyższym poziomie w porównaniu do państw posiadających preferencyjne systemy podatkowe.

Można postawić również tezę, zgodnie $\mathrm{z}$ którą UKSZ powinno zostać wprowadzone do polskiego systemu prawa podatkowego. Do tej pory ustawodawca nie zdecydował się na taki krok, być może ze względu na to, że w pierwszych kilkunastu latach od czasu transformacji politycznej i gospodarczej liczba zagranicznych inwestycji dokonywana przez polskich podatników była niewielka ${ }^{38}$. Ze względu na to także transfer polskiego kapitału za granicę i potencjalne wpływy z opodatkowania KSZ do Skarbu Państwa wydawały się nieznaczne. Niemniej jednak w okresie obecnego szybkiego wzrostu gospodarczego oraz procesów integracji w gospodarce wielu polskich podatników prowadzących średnie i duże przedsiębiorstwa realizuje zagraniczne inwestycje za pośrednictwem KSZ. W tym kontekście warto zauważyć, że w ciągu ostatniej dekady obserwuje się znaczny wzrost liczby zagranicznych inwestycji realizowanych przez polskich przedsiębiorców ${ }^{39}$. Przy czym najwięcej zagranicznych inwestycji realizowanych przez polskich przedsiębiorców jest lokowanych w państwach o preferencyjnych reżimach podatkowych, takich jak Luksemburg, Szwajcaria, Holandia czy też Cypr. Polscy przedsiębiorcy dokonują także wielu inwestycji za pośrednictwem spółek założonych w państwach i terytoriach sklasyfikowanych przez OECD jako prowadzące szkodliwą konkurencję podatkową (raje podatkowe) ${ }^{40}$. Co więcej, większość polskich inwestycji w tych krajach miała jedynie charakter przepływów finansowych między polskimi spółkami dominującymi a ich spółkami zależnymi, funkcjonującymi najczęściej jako spółki holdingowe nieprowadzące rzeczywistej działalności

38 Por. M. Rudnicki, Ł. Szczygielski, Przeglad regulacji CFC w wybranych pañstwach Unii Europejskiej w rok po wyroku ETS w sprawie Cadbury Schweppes (C-196/04), „Monitor Podatkowy”2007, nr 7, wersja elektroniczna.

39 W latach 1994-2000 wartość polskich inwestycji bezpośrednich za granicą pozostawała na zbliżonym poziomie nieprzekraczającym 50 mln EURO rocznie, z wyjątkiem 1998 r. (316 mln EURO).W kolejnych latach nastąpiło przyspieszenie w zakresie polskich bezpośrednich inwestycji zagranicznych i wartość kapitału transferowana z tego tytułu za granicę wzrosła z $228 \mathrm{mln}$ EUR w 2002 r. do 2730 mln EUR w roku 2005, a w 2006 wyniosła rekordowo 7052 mln EURO. W latach 2007-2009 liczby te kształtowały się odpowiednio na poziomie $3952 \mathrm{mln}$ EURO, $3011 \mathrm{mln}$ EURO, 3745 mln EURO. Źrodło: Polskie Inwestycje Bezpośrednie w 2009 roku, Departament Analiz i Prognoz Ministerstwa Gospodarki, Warszawa, maj 2011.

40 Informacje w tym zakresie są ograniczone ze względu na brak skutecznego środka prawnego pozwalającego na uzyskanie informacji podatkowych przez polskie organy skarbowe od organów skarbowych właściwych dla spółek podlegających opodatkowaniu w tych państwach. 
gospodarczej ${ }^{41}$. Zatem inwestycje te były realizowane w ramach struktur, które są często wykorzystywane do agresywnej optymalizacji podatkowej. Można więc uzupełnić postawioną wcześniej tezę, iż brak przepisów dotyczących KSZ pociąga za sobą znaczne ograniczenie wpływów budżetowych $z$ tytułu podatków dochodowych od osób fizycznych i od osób prawnych. Przy czym odpowiednia zmiana obecnie obowiązującego ustawodawstwa w celu wprowadzenia UKSZ powinna zostać poprzedzona wnikliwą i szeroką analizą problematyki stosowania tych przepisów.

\section{BIBLIOGRAFIA}

Arnold J. B., The Taxation of Controlled Foreign Corporations: An International Comparison, Canadian Tax Foundation, Toronto 1986.

Białocerkiewicz J., Status prawny cudzoziemca w świetle standardów międzynarodowych, Toruń 1999.

Biegalski A., Pojęcie i zakres jurysdykcji podatkorwej państwa, „Kwartalnik Prawa Podatkowego" 1999, nr 1.

Biegalski A., Jurysdykcja podatkowa, [w:] B. Brzeziński (red.), Prawo podatkowe. Teoria. Instytucje. Funkcjonowanie, TNOiK 2009.

Brian A. J., Hugh J. A., Comparative Income Taxation: A Structural Analysis, 2nd edition, The Hague: Kluwer Law International 2004.

Brzeziński B., Wstęp do nauki prawa podatkowego, Wyd. TNOiK, Torun 2003.

Eckl P., The Tax Regime for Controlled Foreign Corporations, „European Taxation”, January 2003.

Fontana R., The Uncertain Future of CFC Regimes in the Member States of the European Union - Part I E Part II, „European Taxation”, June/July 2006.

Hensel A., Steuerrecht, wyd. 3, Berlin 1927.

Honjo T., Cahiers de droit fiscal international: Limits on the Use of Low-Tax Regimes by Multinational Business: Current Measures and Emerging Trends, vol. LXXXVIb (2001).

Joseph A., Changes to Controlled Foreign Company Rules, „Derivatives \& Financial Instrument", May/June 2008.

Kalir D. M., Taking Globalization Seriously: Towards General Jurisprudence, „Columbia Journal of Transnational Law" 2001, no. 39.

Kapoor S., Commentary on New Code Expected in 2008. Anti-Avoidance and Tax in Small Huge World, „International Transfer Pricing Journal” 2008, no. 1/2.

Korczyński I., Podatkowoprawny stan faktyczny, [w:] B. Brzeziński (red.), Prawo podatkowe. Teoria. Instytucje. Funkcjonowanie, TNOiK 2009.

41 E. Radomska, Bezpośrednie Inwestycje Zagraniczne (BIZ) polskich firm, „Zarządzanie Zmianami - Biuletyn Polish Open University”, maj 2010, nr 5 (39), wersja elektroniczna: http://www. wsz-pou.edu.pl/biuletyn/index.php?nr=27\&p=\&strona=biul_radom_biz. 
Kuros S., Niektóre aspekty opodatkowania inwestycji bezpośrednich w świetle polsko-niemieckiej umowy o unikaniu podwójnego opodatkowania, „Monitor Podatkowy” 2000, nr 5.

Lang M., CFC Legislation and Community Law, „European Taxation”, September 2002.

Lang M., CFC Regulations and Double Taxation Treaties, „Bulletin - Tax Treaty Monitor”, February 2005.

Lang M., Aigner H.-J., Scheuele U., Stefaner M. (red.), CFC Legislation, Tax Treaty and EC Law, Eucotax on European Taxation Series, „Kluwer Law International” 2004, vol. 8.

Małecki P., Mazurkiewicz M., CIT. Podatki i Rachunkowośc. Komentarz do art.12 ustawy o podatku dochodowym od osób prawnych, wyd. 2, LEX 2011, wersja elektroniczna, LEX I.

Martha J., The Jurisdiction to Tax in International Law. Theory and Practice of Legisltaive Fiscal jurisdiction, Denver-Boston 1989.

Popkin W. D., The Taxation of Foreign Incorporated Pocketbooks With Nonresident Alien Shareholders, „20 Rutgers Law Review” 1965-1966, no. 268.

Prebble J., Controlled Foreign Company Regimes and Double Taxation, „Asia-Pacific Tax Bulletin", January/February 2006.

Radomska E., Bezpośrednie Inwestycje Zagraniczne (BIZ) polskich firm, „Zarządzanie Zmianami - Biuletyn Polish Open University", maj 2010, nr 5 (39).

Rudnicki M., Szczygielski Ł., Przeglad regulacji CFC w wybranych państwach Unii Europejskiej w rok po wyroku ETS w sprawie Cadbury Schweppes (C-196/04), „Monitor Podatkowy" 2007, nr 7.

Sandler D., Controlled Foreign Corporation Rules and Developing Economies, 2004.

Schönfeld J., The Cadbury Schweppes Case: Are the Days of the United Kindon's CFC Legislation Numbered?, „European Taxation”, October 2004.

Stiglitz J. E., The General Theory of Tax Avoidance, „National Tax Journal”2001, vol. XXXVII. Templemann L., Tackling Tax Avoidance, [w:] A. Shipwright (ed.), Tax Avoidance and the Law. Sham, Fraud or Mitigation, Key Haven Publications PLC, Oxford 1997.

Vogel K., Taxation of Foreign Income - Principles and Practice, BIFD 1985.

\section{ORZECZNICTWO}

Wyrok Stałego Trybunału Sprawiedliwości Międzynarodowej w sprawie Affaire du Lotus, 7 sèptembre 1927 (France c. Turquie), Recueil des Arre',ts, Sèrie A, No 10, Leyde 1927.

Wyrok Naczelnego Sądu Administracyjnego w Warszawie z dnia 16 listopada 2006 r., sygn akt II FSK 1375/05, LEX nr 291825.

\section{AKTY PRAWNE}

Internal Revenue Code of 1986.

Francuski Kodeks Kodatkowy (Code Général des Impôt, Version consolidée au 1 septembre 2011).

Revenue Act of 1913.

Revenue Act of 1934. 
Ustawa z 23 kwietnia 1964 r. - Kodeks cywilny, Dz. U. nr 16, poz. 93 ze zm.

Ustawa o podatku dochodowym od osób fizycznych z 26 lipca 1991 r., Dz. U. nr 80, poz. 360 , ze zm.

Ustawa o podatku dochodowym od osób prawnych z 15 lutego1992 r., Dz. U. nr 21, poz. 86 , ze zm.

Ustawa z dnia 15 września 2000 r. - Kodeks spółek handlowych, Dz.U.00.94.1037 ze zm.

\section{INNE}

Commentary on the Model Tax Convention On Income And On Capital. Condensed Version 22 July 2010. OECD - Organization for Economic Co-operation and Development.

Model Konwencji w Sprawie Podatków od dochodu i Majątku opracowany przez Komitet do spraw Podatkowych Organizacje Wspólpracy Gospodarczej i Rozwoju (wersje z 2003, 2005 i 2010 r.).

OECD Progress Report on the Jurisdictions Surveyed by the OECD Global Forum in Implementing the Internationally Agreed Tax Standard.

Polskie Inwestycje Bezposrednie w 2009 roku, Departament Analiz i Prognoz Ministerstwa Gospodarki, Warszawa, maj 2011.

Raport OECD, Stosowanie Modelu Konwencji OECD do spótek osobowych, 1999.

\section{STRESZCZENIE}

Artykuł porusza problematyką opodatkowania kontrolowanych spółek zagranicznych (określanych tu za pomocą skrótu CFC) w świetle współczesnego procesu integracji gospodarczej, międzynarodowego prawa podatkowego i prawa Unii Europejskiej.

W ogólnym ujęciu przepisy dotyczące kontrolowanych spółek zagranicznych (przepisy CFC) można zdefiniować jako określone działania mające na celu zwalczanie unikania podatków, które nadają prawo krajowi, z którego pochodzą udziałowcy, do przypisania pewnej części dochodu osiągniętego przez spółkę CFC jej udziałowcom i następnie opodatkowania tego dochodu. Przepisy CFC można zastosować albo gdy spółka jest traktowana jako podmiot transparentny (podmiot pomijany przez prawo/usunięcie metod ukrywania), albo gdy spółka nie dzieli zysku wypracowanego przez nią i przypadającego udziałowcom (metoda przypisania dywidend do wartości udziału). Należy zauważyć, że bez zastosowania przepisów CFC opodatkowanie - w kraju, z którego pochodzą udziałowcy - dochodu wypracowanego lub otrzymanego przez CFC jest odroczone aż do momentu podziału zysków przez spółkę CFC wśród jej udziałowców. Ponadto, jeśli dana spółka CFC jest zarejestrowana w jurysdykcji, w której nie ma obciążenia podatkowego, lub też jest, ale obowiązują tam bardzo niskie stawki podatkowe, dla przykładu jurysdykcja tzw. rajów podatkowych lub państw/regionów $z$ bardzo liberalnym systemem podatkowym i gdzie dywidendy nigdy nie są wypłacane udziałowcom, dochód nie jest ostatecznie przedmiotem opodatkowania. Podsumowując, tym, co charakteryzuje przepisy dotyczące spółek CFC, jest dążenie do uniknięcia utraty wpływów podatkowych w krajach o dużym obciążeniu podatkowym przez zawężanie możliwości nadużywania tworzenia spółek międzynarodowych tylko w celu uniknięcia podatków. 


\title{
INTRODUCTION TO THE PROBLEMS OF TAXATION OF "CONTROLLED FOREIGN COMPANIES"
}

\begin{abstract}
SUMMARY
This article deals with the problems of taxation of controlled foreign companies (hereinafter: CFC) in the light of the contemporary process of economic integration, international tax law and the European Union law. In general, the Controlled Foreign Companies rules (hereinafter: $\mathrm{CFC}$ rules) can be defined as specific anti-tax avoidance measures that grant the right of the shareholders' country to attribute certain income generated by CFC to its shareholders and subsequently levy tax on it. The CFC rules may be applied either by regarding the company as a transparent entity (disregarded legal entity/piercing the veil approach), or deeming a distribution of the undistributed profits generated by the foreign company to the shareholder (deemed dividend approach). It should be noted that without the CFC rules, taxation - in the shareholders' country - of income generated or received by a CFC is deferred until the distribution of profits by the CFC to its shareholders. Furthermore, if the CFC is established in a jurisdiction that does not impose taxes or imposes taxes at the very low rates, for instance a tax haven, or in a state or territory with a lenient tax regime, and the dividends are never distributed to the shareholders, the income is not subject to tax eventually. Thus, in nutshell, a common feature of the CFC rules is not to lose tax revenue in high tax countries by curbing the abuse of companies established on an international level for the sole purpose of avoiding taxation.
\end{abstract}


